\section{World at work: Marble quarrying in Tuscany}

\section{G Angotzi, L Bramanti, D Tavarini, M Gragnani, L Cassiodoro, L Moriconi, P Saccardi, I Pinto, N Stacchini, M Bovenzi}

\section{Job hazards and preventive measures for workers}

$\mathrm{S}$ ince the beginning of the Christian era, the Apuanian Alps between the provinces of Massa Carrara and Lucca in Tuscany, have been a centre for the excavation of white marble, venato and arabescato, and Cardoso stone. Marble is a metamorphic rock composed of calcium carbonate with a quartz content of less than $1 \%$. Cardoso stone (from the name of the village of Cardoso) is a dark grey metamorphic sandstone made up of alternate thin layers of microgranular quartz and carbonate, as well as lamellas of disorientated mica, for example muscovite, with a quartz content of $60 \%$. They are precious materials, used in Italy and worldwide to cover surfaces and flooring or as an architectural or structural element in building and for the realisation of sculptures. To prevent, as much as possible, the alteration or breakage of the material, the methods used for extracting this stone are different to those adopted for the extraction of rocks used in the building or chemical industry.

\section{THE QUARRYING INDUSTRY IN THE APUANIAN ALPS}

The quarrying industry in the Apuanian Alps directly employs about 1000 workers in the area of Massa Carrara and 200 in Alta Versilia (a small mountainous area in the Province of Lucca), including the transporters of the extracted material from the quarries to the processing and commercialisation locations. The workers are exclusively male. To be a quarryman, specific professionalism is required, only attained with a long apprenticeship in the local quarries. In Alta Versilia the average age of the quarrymen is about 40 years and the specific length of service is high (over 10 years).

In the same area, the excavation, or to use the formal term "exploitation", is carried out at an altitude between 200 and 1600 metres above sea level. Because of the altitude some quarries close during the winter months due to snow and ice. In most cases, the quarries are connected to the ordinary road network by internal roads (some of which are asphalted), known as access roads, often very steep. The blocks of stone are transported downhill exclusively by truck. An average journey from the quarry site to the valley takes about 1-2 hours. Until now, excavation has almost always been carried out in the open air, but recently underground exploitation has developed, partly because of the environmental protection laws set up by the Regional Park, where all the quarries in Alta Versilia are located. At present, there are 41 working sites in Alta Versilia, with a workforce that varies between 3 and 40 men at each quarry site. Figure 1 shows an overview of a quarry site.

The method of extraction is homogeneous in all quarry sites (open caste, pit, underground). In chronological order the operations consist of: research for new sites; preparation of the quarry site; productive exploitation of the quarry site; and establishing the safety and environmental restoration of the worked-out or abandoned quarry. The entire cycle can last many years.

The productive exploitation consists of separating portions of rock in shapes as regular as possible (cubes and paral-

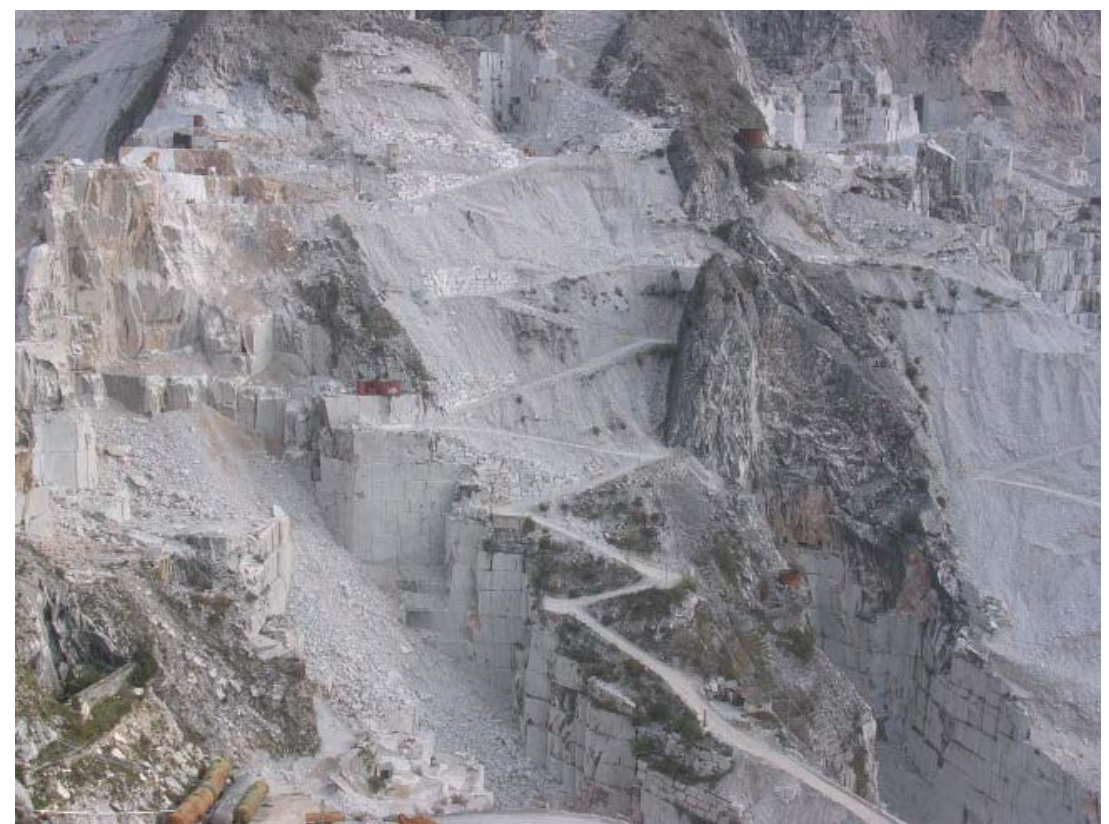

Figure 1 Quarry site: internal roads and "ravaneti". lelepipeds) from the wall of the mountain through complex operating phases, that entail the drilling of horizontal and vertical holes in the mountain with hydraulic or pneumatic perforating hammers. A cable called a diamond wire is inserted in the drilled holes. This wire is part of a machine (diamond wire saw) that cuts through the selected portion of mountain (called the bench) by making use of the abrasive effect of the cable on the wet stone. This phase, called "quarry bench cutting" can be carried out with the use of a chain saw (machine with a diamond saw blade) that can directly wet cut without the necessity of previously drilled holes. After cutting, the rock portion, called bench, of various heights, usually from 3 to 9 metres and an average thickness of about 3 metres (corresponding to tens of cubic metres), is separated from the mountain by the interposition of an iron apparatus that acts as a wedge (piston jacks, metal cushions filled with compressed water) and, with the vehicle's push (excavator, wheel, or track loader), is overturned on a bed of rubble previously prepared on the quarry floor (fig 2).

At this point the bench, already broken into several pieces by the fall, is cut again into commercial sized blocks using the same machines. Lastly, the blocks are loaded onto trucks by lifting machines (derricks) or mechanical vehicles (wheel or track loaders) for transportation downhill (fig 3).

The waste material deriving from these operations is removed from the quarry site and pushed down into the valley by the loader to form piles of waste material called "ravaneti", that 


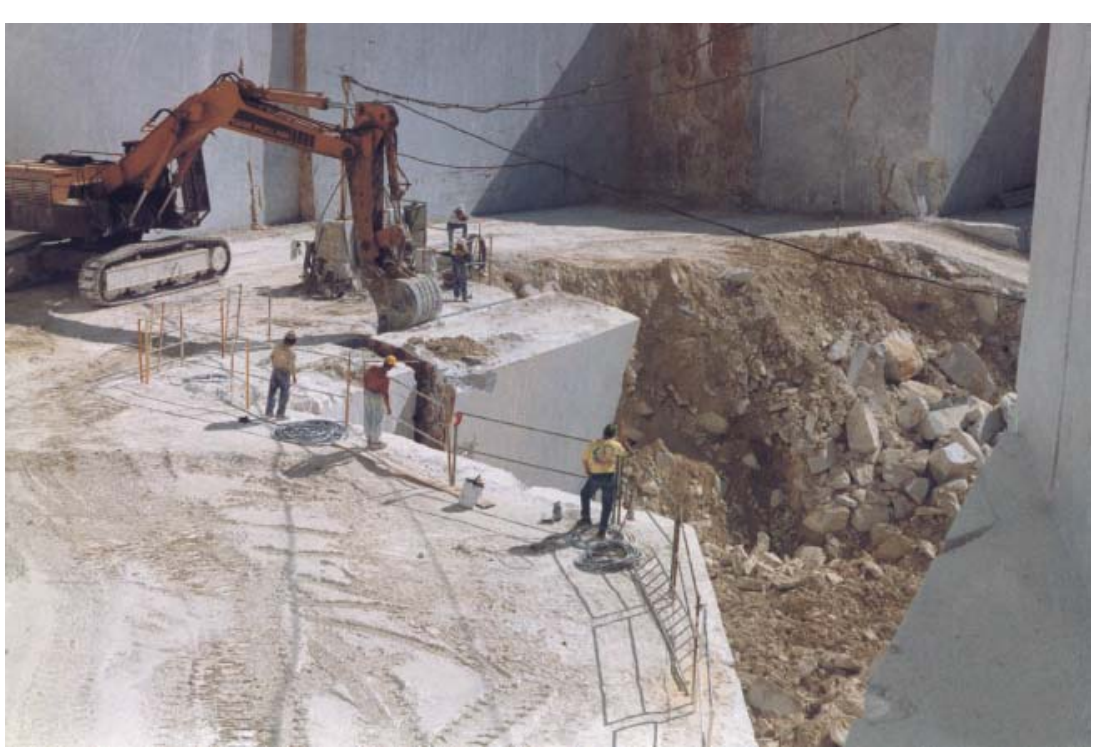

Figure 2 Overturning of the bench with an excavator.

over the years have become landmarks of the Apuanian Alps. The big portions of non-commercial blocks are reduced to rubble by hammer or small charges of explosives. In the last few years the "ravaneti" are also being exploited and the extracted material is used in the chemical and building industries.

Table 1 summarises the work organisation in a quarry site, including work phases, work processes, and the associated health and safety risks for workers.

\section{OCCUPATIONAL RISKS}

Accidents

All the phases of the production cycle have a high manual character, needing

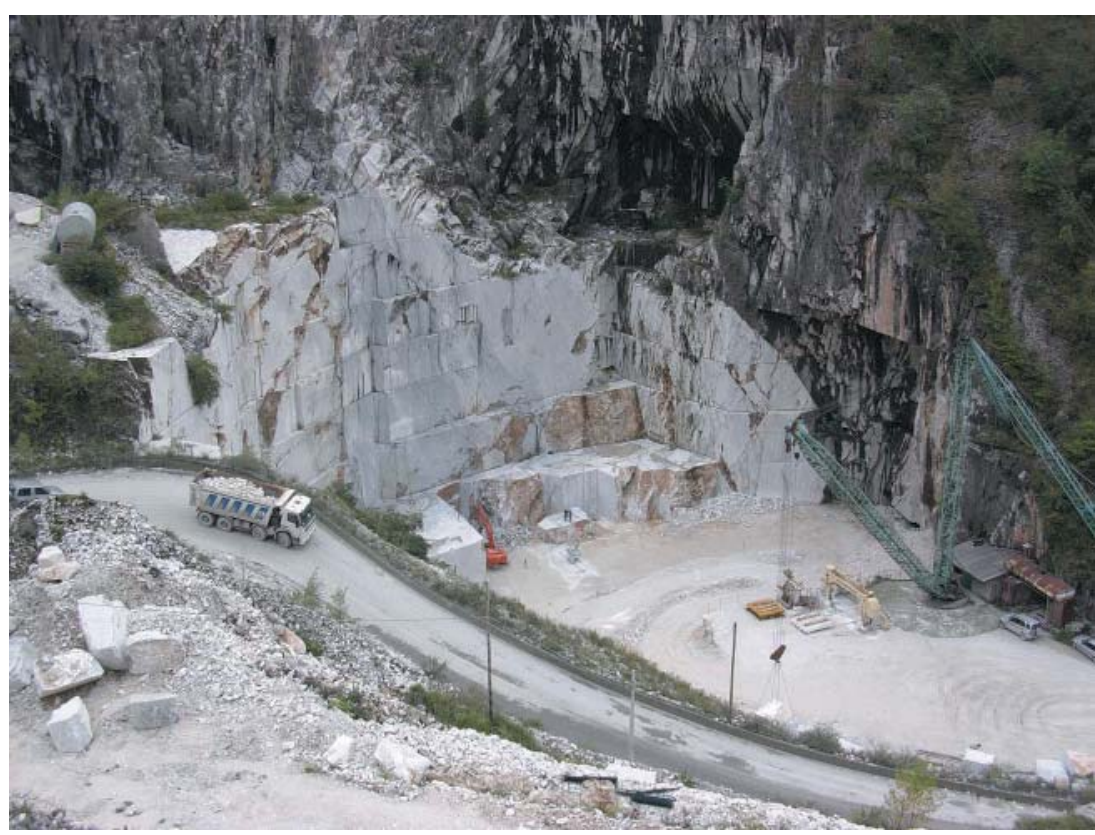

Figure 3 Quarry site: rubble transport (a derrick and an excavator are visible).

\section{Climate and lighting}

Quarry workers are exposed to several health risks. Some are of a general nature: working in the open means being exposed to macroclimatic conditions and solar radiation, accentuated by the reflection from the white marble floor and walls. The effects are temporary blindness with major risk of accidents, photoconjunctivitis and photokeratitis, dermatitis, and possible sunstroke in the summer months. In the underground quarries the climate is hot and humid, responsible for thermal stress for workers operating alternatively outside and underground, with onset of frequent disorders of the respiratory tract and muscular contraction in various parts of the body (particularly the lumbar and cervical spinal tract and shoulder girdle).

Other health risks are due to specific occupational hazards: loud industrial noise, hand transmitted vibration, whole body vibration, dust with variable quartz content, vehicle exhaust fumes and gases (underground), and intense muscle strain with spinal stress.

Furthermore, the workplace is in the open or underground, isolated, and on high mountains. Therefore, the major risks concern the safety of the workers. In the Massa Carrara area, from 1994 to 1998 there have been over 200 accidents a year, of which 10 were very serious or fatal. ${ }^{1}$ Likewise, in Alta Versilia from 1999 to 2004 there have been about 20 accidents a year, of which at least three were very serious. In Alta Versilia and Massa Carrara the most serious accidents occurred in the same way (table 2).

\section{Noise}

The main sources of noise, expressed in terms of equivalent continuous Aweighted sound pressure level ( $\left.L_{\text {Aeq }}\right)$ according to International Standard ISO $1999,{ }^{2}$ are given by perforating hammers during rock drilling (average $L_{\mathrm{Aeq}}$ $112 \mathrm{~dB})$, wheeled vehicles ( $L_{\text {Aeq }} 87-$ $94 \mathrm{~dB}$ ), track vehicles with noise exposure during assistance in block loading ( $\left.L_{\text {Aeq }} 91-103 \mathrm{~dB}\right)$, preparation of the rubble bed, and other activities that necessitate proximity between workers and vehicles, particularly when underground. The $L_{\text {Aeq }}$ produced by an accessory for the excavator (called big hammer) averages $95 \mathrm{~dB}$; it is used to break up non-commercial blocks to make them easier to clear away. Less noise is produced by the diamond wire cutter $\left(L_{\mathrm{Aeq}} 70 \mathrm{~dB}\right)$ and the chain saw ( $\left.L_{\text {Aeq }} 75-80 \mathrm{~dB}\right)$. However, noise exposure is generally discontinuous because the various work phases do not entail the constant use of noisy tools or vehicles. Moreover, suspension of work, due to bad weather or during the winter season, tends to reduce the risk of occupational noise induced hearing loss. For this reason and following the improvement of working conditions (for example, the appearance on the market of pneumatic drills equipped with silencers), as well as the regular use of hearing protectors among quarrymen in the past 10 years, no new cases of noise induced hearing loss have been recently discovered during medical surveillance. 
Table 1 Work phases, work processes, and occupational risk factors

\begin{tabular}{|c|c|c|}
\hline Work phase & Description of processing steps & Health and safety risks \\
\hline $\begin{array}{l}\text { 1. Quarry front cutting } \\
\text { 1a) Preliminary operations }\end{array}$ & $\begin{array}{l}\text { Inspection of work area and marking of } \\
\text { cutting lines on quarry bench } \\
\text { Clearing of bench }\end{array}$ & $\begin{array}{l}\text { Falling from above } \\
\text { Collapsing of mountain } \\
\text { Traumas due to stones falling from mountain } \\
\text { Accident while assisting moving vehicles }\end{array}$ \\
\hline 1b) Hole drilling & $\begin{array}{l}\text { Assembling, starting, control and dismantling } \\
\text { of drilling machine; alternatively use of } \\
\text { pneumatic hammer }\end{array}$ & $\begin{array}{l}\text { Being hit with projected parts of the diamond wire } \\
\text { Whiplash caused by wire breakage } \\
\text { Manual lifting and movement of loads }\end{array}$ \\
\hline $\begin{array}{l}\text { 1c) Cutting with diamond } \\
\text { wire saw }\end{array}$ & $\begin{array}{l}\text { Positioning of diamond wire saw and } \\
\text { control unit } \\
\text { Positioning of wire } \\
\text { Positioning of mobile protections for wire } \\
\text { Periodic checks on wire during cutting }\end{array}$ & $\begin{array}{l}\text { High level of noise from drilling hammers } \\
\text { Dust when dry drilling and from the rising dust } \\
\text { sediments from the quarry floor } \\
\text { Hand transmitted vibration from pneumatic hammers } \\
\text { Whole body vibration from earth-moving machines }\end{array}$ \\
\hline 1d) Cutting with chain saw & $\begin{array}{l}\text { Positioning of machine, control and } \\
\text { dismantling after cutting }\end{array}$ & Gas and diesel exhaust fumes (when the site is underground) \\
\hline \multicolumn{3}{|l|}{ 2. Overturning of bench } \\
\hline 2a) Preparation & Use of pneumatic hammer to drill holes & $\begin{array}{l}\text { Falling from above } \\
\text { Overturning and rolling over of vehicles }\end{array}$ \\
\hline $\begin{array}{l}\text { 2b) Preparation of } \\
\text { rubble bed }\end{array}$ & $\begin{array}{l}\text { Collecting of waste material with loader } \\
\text { and depositing at base of quarry bench }\end{array}$ & $\begin{array}{l}\text { Accident while assisting moving vehicles } \\
\text { Explosion of hydraulic cushions with projection of metal parts }\end{array}$ \\
\hline $\begin{array}{l}\text { 2c) Movement with } \\
\text { cushions, jacks }\end{array}$ & $\begin{array}{l}\text { Manual insertion of cushions and piston } \\
\text { jacks and wedging cut with stones }\end{array}$ & $\begin{array}{l}\text { Manual liffing and movement of loads } \\
\text { Repetitive movements of upper limbs when using } \\
\text { sledgehammers and other manual tools }\end{array}$ \\
\hline 2d) Pushing with excavator & $\begin{array}{l}\text { Pushing bench by inflation of the } \\
\text { cushions and with piston jacks } \\
\text { Driving excavator on top of bench } \\
\text { and pushing with bucket }\end{array}$ & $\begin{array}{l}\text { High noise level from drilling hammers } \\
\text { Hand transmitted vibration from pneumatic hammers } \\
\text { Whole body vibration from earth-moving machines } \\
\text { Dust from dry drilling and the dust rising from the } \\
\text { sediment on the quarry floor } \\
\text { Gas and diesel exhaust fumes (when the site is underground) }\end{array}$ \\
\hline \multicolumn{3}{|c|}{ 3. Handling of work material in quarry } \\
\hline $\begin{array}{l}\text { 3a) Transport of blocks to } \\
\text { deposit or onto truck }\end{array}$ & $\begin{array}{l}\text { Manoeuvring with derrick or, alternatively, } \\
\text { lifting and transporting with loader }\end{array}$ & $\begin{array}{l}\text { Accident when assisting moving vehicles } \\
\text { Overturning and rolling over of vehicles }\end{array}$ \\
\hline $\begin{array}{l}\text { 3b) Transport of waste } \\
\text { material to quarry waste area }\end{array}$ & $\begin{array}{l}\text { Using shovel and mini-loader to collect small } \\
\text { pieces in restricted spaces and transfer them } \\
\text { to loading area } \\
\text { Collecting and carrying to edge of quarry } \\
\text { with loader } \\
\text { Pushing waste material down mountain slope }\end{array}$ & $\begin{array}{l}\text { Manual liffing and moving of loads } \\
\text { Whole body vibration from loaders } \\
\text { Dust rising from sediment on quarry floor } \\
\text { Gas and diesel exhaust fumes (when the site is underground) }\end{array}$ \\
\hline \multicolumn{3}{|l|}{ 4. Transport of blocks to destination } \\
\hline $\begin{array}{l}\text { 4a) Driving truck on access } \\
\text { roads inside the quarry }\end{array}$ & $\begin{array}{l}\text { Driving vehicle along steep, zig-zagged, } \\
\text { narrow, dirt track roads, often having to move } \\
\text { alternatively forwards and backwards due to } \\
\text { lack of space for manoeuvring the truck round } \\
\text { the bends }\end{array}$ & Overturning and rolling over of truck \\
\hline $\begin{array}{l}\text { 4b) Driving of vehicle on } \\
\text { normal roads }\end{array}$ & $\begin{array}{l}\text { Driving around bends and down mountain } \\
\text { roads to the valley, having to brake frequently }\end{array}$ & Whole body vibration from trucks \\
\hline
\end{tabular}

\section{Mechanical vibration}

Quarrymen may be exposed to either hand transmitted vibration or whole body vibration.

Exposure to hand transmitted vibration arises from the use of pneumatic drills of variable weight, sometimes more than $12 \mathrm{~kg}$. Workers hold pneumatic percussive tools to drill vertical and horizontal holes in the mountain and to cut stones after the overturning of the bench. The use of pneumatic drills is very frequent, mainly in the Cardoso quarries and in the pit quarries. The vibration total value of the frequency weighted accelerations generated by the pneumatic drills ranges 16 to $24 \mathrm{~ms}^{-2}$ r.m.s. according to International Standard ISO 5349. ${ }^{34}$ The adverse health effects of hand transmitted vibration are aggravated by exposure to both cold climate and extremely cold water coming directly from the mountain canals or the water cisterns. Moreover, the complexity of several work operations prevents quarrymen from wearing padded gloves. Long term exposures to hand transmitted vibration and cold climate at the workplace are associated with the onset and development of vibration induced white finger (secondary Raynaud's phenomenon), chronic osteoarticular disorders in the elbow and wrist, tenosynovitis, and Dupuytren's contracture.

Driving vehicles (excavators and wheel or track loaders), as well as driving offroad vehicles on the access roads to reach the various quarry faces, is associated with exposure to whole body vibration and shocks affecting the lumbar spine. The frequency weighted acceleration magnitude of vibration measured on the seat of the industrial vehicle used in quarry varies from 0.7 to $1.8 \mathrm{~ms}^{-2}$ r.m.s. according to International Standard ISO 2631-1. ${ }^{56}$ At present, the vehicle fleet of Alta Versilia is mostly made up of vehicles constructed over 10-15 years ago. Daily driving time averages $2-3$ hours a day in small quarries, where the same workers perform a variety of jobs. Only in large quarries are workers exclusively assigned to driving vehicles. In any case, drivers are chosen from those with the best psychophysical performance and ability. In spite of this selection process, many drivers 
Table 2 Types of serious or fatal accidents at the workplace

\begin{tabular}{l} 
Type of accident \\
\hline Falling from above of worker on foot or \\
when driving vehicles \\
Being hit with stones or parts of block, \\
hit by projection of fragments of material \\
Projection of pieces of diamond wire or \\
whiplash from wire \\
Slipping up of workers on foot
\end{tabular}

Place and phase of work

From the bench, from the marble wall, the quarry's edge, or the access roads

Block squaring, block handling, ground assistance in the various operations, during movement of vehicles, during transit in quarry

During quarry bench cutting and block squaring. The injured workers have been

hit even when at a considerable distance from the cutting area. The kinetic energy of the wire's components is very high

During various work phases, on the paths to the marble wall or other work areas, and in work areas in the presence of mud suffer from low back pain or discomfort. In some cases permanent damage to the lumbar spine is diagnosed (vertebral osteoarthrosis, disc prolapse, or herniation).

\section{Dust}

Inhalable dust is produced when the stone is cut and by the breaking of the stones on the quarry floor during the transit of the vehicles. The bench and block cutting is wet, with minimal exposure to fine dust when assisting the cutting. Nevertheless, when the mud dries on the quarry floor, workers are exposed to the inhalation of dust raised by the wind and the transit of the vehicles.

The dust, in the case of Cardoso stone, contains quartz which can cause silicosis, depending on the amount of quartz actually present in the dust and the diameter of free silica particles. ${ }^{7}$ In many work operations, the exposure level to respirable dust is above the ACGIH TLV-TWA. ${ }^{8}$

In marble quarries, workers, particularly the older ones, are affected by chronic obstructive respiratory diseases due to occupational and individual causes: dust with a low content of crystalline silica, exposure to unfavourable macroclimatic conditions, and tobacco smoking.

\section{Exhaust fumes and gases}

Underground exploitation is associated with workers' exposure to exhaust fumes and gases from diesel engines. As an acute consequence, a fair amount of workers, particularly the drivers of vehicles without cabs, report irritation and inflammation to the upper mucous membranes, such as conjunctivitis and rhinitis. The galleries are equipped with ventilation systems, but their efficiency is variable and depends on the geographical characteristics of the quarry site. Only the most recently built vehicles are supplied with a booklet containing the average quantitative and qualitative readings of fumes and gases produced in normal use. The older vehicles are not equipped with these technical facilities and the emission of fumes and gases depends on the general maintenance of the vehicle.

\section{Adverse ergonomic factors}

Quarrying is a very tiring and stressful activity and the implementation of ergonomic procedures is not easy. Various pieces of heavy iron apparatus must be moved to different areas in the workplace (the tracks for the diamond wire machine, cables, piston jacks, plug and feathers, hydraulic cushions, hammers, and sledgehammers). When it is not possible to use lifting machinery or other vehicles, two or three workers lift and manually drag heavy loads (for example, tracks weighing $18-20 \mathrm{~kg}$ each). Frequently manual shovelling is carried out to clear the remaining rubble and mud, which is loaded onto handcarts or directly into the bucket on the loader. The external quarry sites change rapidly and usually do not have a storage place for the equipment that is frequently deposited on the ground and needs lifting in ergonomically unfavourable conditions. The stones too, if they cannot be reached with the machinery, must be moved by hand. Repetitive manual lifting and moving is a frequent cause of acute low back pain, pulled neck and shoulder muscles, and permanent damage to the spine. Among other problems, tendon and muscle injuries caused by strains and uncoordinated movements are also frequent.

\section{PREVENTIVE MEASURES}

Some accident prevention measures are specific to quarrying ornamental stones, such as the "exploitation plan", protection of the vehicle driver's seat with structures like ROPS, FOPS (see below), and TOPS ("tip over protection structure"), plasticised diamond wire, protection of the wire during cutting, clearing of the marble wall, and the parapets in the transited areas and the high work areas on the site.

The "exploitation plan" is the excavation project in a quarry site. From the safety point of view it is necessary to ensure the following protection measures:

- Access roads with adequate gradients and widths for the vehicles to be used

- Protection of the overhead rock portions on the marble wall with suitable retention systems to prevent the fall of small rock portions

- Systematic survey of the fractures in the rock ("geomechanical analysis")

- Analysis of the stability of the quarry face to prevent collapsing

- Analysis of the underground stability (including the vault and pillars)

- Suitable dimensions of the bench levels, both in width and length, to achieve the stability of the quarry face, to guarantee adequate work space and the right conditions for establishing safety and environmental restoration after exploitation

- Appropriate anchorage of the derricks

- Appropriate ventilation system for the underground quarries

- Emergency exits.

The protection of the driver's seat on the quarry vehicles must be able to resist objects hitting the roof ("front objects protective structure", FOPS) and the cabin's windscreen ("front guard protective structure", FGPS), and to withstand the overturning of the vehicle ("roll over protective structure", ROPS), according to the current technical standards.

The breakage, through wear and tear, of the diamond wire brings about the projection of the diamond elements ("diamond beads") at a very high speed, and the whiplash of the remains of the broken wire in the opposite direction to the cutting movement. The diamond wire is tens of metres long and varies in number, depending on the type of cut. To prevent the projection of the wire's components, the metallic cable and the accessories are impregnated with a resin, considerably resistant to wear and tear in the correct working conditions. To protect the workers on the quarry floor from the whiplash of the wire, metallic shields, adequately positioned, are used.

Because of the action of atmospheric agents, the marble walls and the quarry faces are subject to fragmentation and increase in the mobility of the fragments with the risk of falling onto the quarry 
floor. Periodical inspections are needed with the subsequent removal of unstable rock portions. To carry out this operation in inaccessible places, an adequate professionalism and the use of alpine techniques are needed.

During quarrying, the parapet must be continually moved according to the advancement of the exploitation in order to protect persons from falling from above.

To reduce health risks due to exposure to chemical and physical agents, both collective and individual preventive measures are currently adopted, together with the implementation of medical surveillance programmes that provide clinical evaluation at least once a year. In addition to health history and physical examination, specific laboratory tests are carried out every one or two years, such as spirometry and chest radiography in quarrymen exposed to dust, fumes, and gas, audiometry in those exposed to noise, and cold test with measurement of finger systolic blood pressure in users of vibratory tools.

To reduce exposure to loud noise when using pneumatic hammers, tools equipped with devices that reduce noise are being introduced. The $L_{\text {Aeq }}$ associated with the use of silenced pneumatic hammers is about $103 \mathrm{~dB}$. Moreover, the workers are trained to use hearing protectors against the noise produced during drilling or when operating close to sources of excessive noise.

To reduce exposure to hand transmitted vibration, it is necessary to replace the older hammers with tools equipped with mechanical dumping devices. The frequency weighted acceleration magnitude of vibration produced by hammers equipped with antivibration devices varies from 4.5 to $8.5 \mathrm{~ms}^{-2}$ r.m.s. Anti-vibration gloves ${ }^{9} 10$ are not efficient in decreasing the transmission of hammer vibration to the hands, even though they protect from low temperatures and, as opposed to traditional gloves, do not impede movement.

To reduce exposure to whole body vibration from industrial vehicles, such as loaders and excavators, the most recently built vehicles have ergonomic seats and are equipped with safety devices and shock isolating mountings. In such vehicles, the frequency weighted acceleration magnitude of vibration measured in the dominant axis ranges from 0.3 to $0.6 \mathrm{~ms}^{-2}$ r.m.s.

To reduce exposure to inhalable dust, prevention measures include scrupulous wet cutting, cleaning of the work area by clearing away the mud by hand or with a mini-loader, and wetting the quarry floor and the access roads, especially in the drier seasons. During these operations, workers wear adequate personal protective equipment devices to protect respiratory airways and lungs.

With regard to exposure to diesel exhaust fumes and gases from the currently used vehicles, there are no reduction systems available on the market proven to be effective and easy to use. The use of integrated systems with oxidising catalytic converters and ceramic filters has recently started. Underground sites have been equipped with ventilation systems, adjustable according to the advancement of the exploitation. In some cases it has been possible to increase the natural ventilation by adequately widening the emergency exits or by creating special openings (sometimes, though, this has worsened the climatic conditions inside, especially in the winter months, and has increased the discomfort of the workers).

Organisational measures are adopted to prevent, as much as possible, the presence of workers on the quarry floor during the transit of vehicles. Sometimes during exploitation, due to the limited height under the vault, drivers of vehicles without cabs must wear suitable protective breathing equipment.

To prevent sunstroke, organisational measures are regularly adopted to avoid work shifts during the hottest hours of the day during the summer season, and adequate clothing and suitable eye protection (unbreakable glasses with filter lenses) are provided.

Manual handling of heavy loads is common in every work phase. The workers, who are specifically trained in safe handling practices, avoid handling of excessively heavy loads by resorting to the use of loaders or excavators to transport the various pieces of equipment, such as cables, hammers, jacks, cushions, etc. On some sites, where it is necessary to install derricks, these latter are also used to move heavy loads.

The disposal of mud and the clearance of the quarry floor is often carried out with a mini-loader, reducing the use of shovels.

A full description of work organisation, work processes, job hazards, health risks, and preventive measures in marble quarrying in Tuscany is available on the $O E M$ website (http://www.occenvmed. com/supplemental).

\section{ACKNOWLEDGEMENTS}

This research was supported by the European Commission under the Quality of Life and Management of Living Resources programme, project no. QLK4-2002-02650 (VIBRISKS), and by the Istituto Superiore per la Prevenzione e la Sicurezza del Lavoro (ISPESL, Rome), contract CM3/DIL/03.
Occup Environ Med 2005;62:417-421 doi: 10.1136/oem.2004.018721

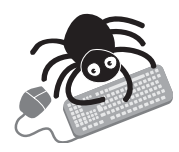

A full description of work organisation, work processes, job hazards, health risks, and preventive measures in marble quarrying in Tuscany is available on the OEM website (http:// www.occenvmed.com/ supplemental)

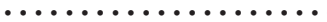

Authors' affiliations

G Angotzi, L Bramanti, D Tavarini, M Gragnani, L Cassiodoro, L Moriconi, P Saccardi, Department of Occupational Medicine, Viareggio Local Health Authority, Italy

I Pinto, N Stacchini, Department of Prevention, Siena Local Health Authority, Italy M Bovenzi, Clinical Unit of Occupational Medicine, Department of Public Health Sciences, University of Trieste, Italy

Correspondence to: Prof. G Angotzi, Servizio di Medicina del Lavoro, Azienda U.S.L.

Viareggio, Via G. Garibaldi, 92, I-55045

Pietrasanta (Lucca), Italy; g.angotzi@usl12. toscana.it

Accepted 18 February 2005

Competing interests: none declared

\section{REFERENCES}

1 Galli G. Cave di marmo di Carrara e Massa. Osservatorio degli infortuni sul lavoro. Analisi degli infortuni accaduti nel quinquennio 19941998. Azienda USL 1 di Massa e Carrara, 1999.

2 International Organisation for Standardisation. Acoustics-Determination of occupational noise exposure and estimation of noise-induced hearing impairment. ISO 1999. Geneva, 1990.

3 International Organisation for Standardisation. Mechanical vibration-Measurement and evaluation of human exposure to handtransmitted vibration. Part 1: General requirements. ISO 5349-1. Geneva, 2001.

4 International Organisation for Standardisation. Mechanical vibration-Measurement and evaluation of human exposure to handtransmitted vibration. Part 2: Practical guidance for measurement at the workplace. ISO 5349-2. Geneva, 2001

5 International Organisation for Standardisation Mechanical vibration and shock-Evaluation of human exposure to whole-body vibration. Part 1: General requirements. ISO 2631-1. Geneva, 1997.

6 Paddan GS, Griffin MJ. Evaluation of whole body vibration in vehicles. J Sound Vib 2002;253:195-213.

7 Ulm K, Gerein P, Eigenthaler J, et al. Silica, silicosis and lung-cancer: results from a cohort study in the stone and quarry industry. Int Arch Occup Environ Health 2004;77:313-18.

8 American Conference of Governmental Industrial Hygienists. Threshold limit values and biological exposure indices. Cincinnati, $\mathrm{OH}$, 2004

9 International Organisation for Standardisation Mechanical vibration and shock-Hand-arm vibration-Method for the measurement and evaluation of the vibration transmissibility of gloves at the palm of the hand. ISO 10819. Geneva, 1996.

10 Hewitt S. Assessing the performance of antivibration gloves - a possible alternative to ISO 10819, 1996. Ann Occup Hyg

1998;42:245-52. 